\title{
Effects of cinnamaldehyde or monensin on performance of weaned Holstein dairy heifers
}

\author{
C. E. Chapman, ${ }^{* 1}$ H. Chester-Jones, $†$ D. Ziegler, † J. A. Clapper, $\ddagger$ and P. S. Erickson ${ }^{* 2}$ \\ *Department of Biological Sciences, University of New Hampshire, Durham 03824 \\ †University of Minnesota Southern Research and Outreach Center, Waseca 56093 \\ ‡South Dakota State University, Brookings 57007
}

\section{ABSTRACT}

The objective of this 70-d study was to determine the effects of the essential oil cinnamaldehyde compared with the ionophore monensin on performance of weaned Holstein dairy heifers. Eighty-four Holstein dairy heifers (91 $\pm 3.33 \mathrm{~d}$ of age; $109 \pm 7.55 \mathrm{~kg})$ were housed in a naturally ventilated curtain sidewall, strawbedded barn in 12 pens with 7 heifers/pen $\left(3.98 \mathrm{~m}^{2} /\right.$ head). Heifers were randomly assigned to 1 of 4 treatments in a completely randomized design: (1) control (CON; carrier, $908 \mathrm{~g}$ of ground corn), (2) monensin sodium $[\mathrm{MON} ; 1 \mathrm{mg} / \mathrm{kg}$ of body weight $(\mathrm{BW})+$ carrier], (3) cinnamaldehyde (CIN1; $1 \mathrm{mg} / \mathrm{kg}$ of $\mathrm{BW}+$ carrier), or (4) cinnamaldehyde (CIN2; $2 \mathrm{mg} / \mathrm{kg}$ of BW + carrier). The treatments were hand-mixed into a $20 \%$ crude protein (CP) whole shelled corn and protein pellet mix fed at $2.21 \mathrm{~kg} /$ heifer daily. Heifers had access to free-choice hay and water daily. Initial BW and hip heights were taken at the start of the study and every other week thereafter until calves reached 23 wk of age. Blood samples were also taken on each weigh day to determine plasma urea nitrogen, glucose, and insulinlike growth factor-1 concentrations. Fecal samples were taken from the same 3 heifers/pen initially and then at $\mathrm{d} 28,56$, and 70 of the study for coccidia counts. Cinnamaldehyde had no performance effects on growth, hay intake, hip height, or blood metabolites compared with MON or CON. Average daily gains were 0.98, $0.99,1.01$, and $1.03 \mathrm{~kg} / \mathrm{d}$, and average hay intakes per pen were $17.08,16.34,18.11$, and $17.60 \mathrm{~kg} / \mathrm{d}$ for CON, MON, CIN1, and CIN2, respectively. Fecal samples by pens indicated the presence of viable coccidia, but the counts were low and not consistent across heifers within each pen. No benefits were associated with supplement-

\footnotetext{
Received August 19, 2016.

Accepted November 10, 2016.

${ }^{1}$ Current address: Penn State Extension-Bradford County, Towanda, PA 18848.

${ }^{2}$ Corresponding author: peter.erickson@unh.edu
}

ing cinnamaldehyde or monensin into grain mixes for weaned heifers.

Key words: cinnamaldehyde, heifer, essential oil, monensin

\section{INTRODUCTION}

The second highest cost to dairy producers is raising replacement heifers because of high feeding expenses and extensive labor (Cady and Smith, 1996). Optimizing feeding programs of dairy calves is imperative for the sustainability and profitability of dairy operations. In the United States, heifers may be fed coccidiostats and ionophores to prevent disease and promote growth, and in 2006, at least half of dairies fed either antibiotics or ionophores to weaned heifers to prevent disease or promote growth (USDA, 2007). The ionophore monensin has a mode of action that specifically targets the Eimeria parasite (Chapman et al., 2010).

The use of antibiotic ionophores, such as lasalocid and monensin, has been very successful in reducing energy and protein losses in the rumen by increasing the VFA propionate, decreasing ammonia nitrogen $(\mathrm{N})$ concentrations, as well as improving feed efficiency in livestock productions (Van Nevel and Demeyer, 1998; Calsamiglia et al., 2007; Benchaar et al., 2008). However, their use in animal feeds is facing reduced social acceptance because of the appearance of residues in livestock products and possible development of antibiotic-resistant bacteria that may pose a risk to human health (Van Nevel and Demeyer, 1998; Calsamiglia et al., 2007; Benchaar et al., 2008). Antibiotic growth promoters used in animal diets have been banned in the European Union since 2006. Therefore, researchers have been investigating alternative ways such as feeding essential oils to improve heifer health status and feed utilization, thereby increasing rate of gain and decreasing the overall cost of heifer rearing (Bento et al., 2013).

Essential oils have been studied since the beginning of the 20th century, and the most important activities of these compounds are antiseptic and antimicrobial 
(Cowan, 1999; Burt, 2004). They are generally recognized as safe for human and animal consumption (FDA, 2004).

In the poultry industry, the use of essential oils has been extensively studied, and Hume et al. (2006) observed that in chickens challenged with Eimeria species, supplementation of a blend of essential oils (Crina; DSM Nutritional Products Inc., Parsippany, NJ) resulted in a decrease in microbial communities and the appearance of an anticoccidial effect. Eimeria species causes coccidiosis, which is still one of the most endemic enteric diseases in broiler production. A blend of essential oils appeared to be effective against Eimeria species in poultry, and it may also be effective against Eimeria in bovines as well (Hume et al., 2006). Cinnamaldehyde $\left(\mathrm{C}_{9} \mathrm{H}_{8} \mathrm{O}\right)$, is a natural chemical compound found in the bark of the cinnamon tree. It is the active component of cinnamon oil (Cinnamonum cassia), accounting for $75 \%$ of its composition (Calsamiglia et al., 2007). It is a phenylpropanoid with antimicrobial activity, and it has been studied in poultry for effects on microbial communities (Hume et al., 2006; Venkitanarayanan et al., 2013); feedlot cattle for feed efficiency effects (Yang et al., 2010; Vakili et al., 2013); and lactating dairy cows for effects on DMI and milk yield and components (Tassoul and Shaver, 2009; Tekippe et al., 2013; Wall et al., 2014). A study was conducted using a commercially available mixture of several essential oils (Rumaxol, Soda Feed Ingredients, Monaco) with dairy heifers of approximately the same age. No differences in ADG, hip height gain, or DMI were found among treatments (Golombeski et al., 2010). However, no data currently exist describing the effects that cinnamaldehyde supplementation has on feed intake, performance, or blood metabolites of dairy heifers.

The objective of this study was to determine the effects of the essential oil cinnamaldehyde compared with the ionophore monensin sodium on performance of weaned Holstein dairy heifers. The hypothesis of this study was that supplementing heifers with cinnamaldehyde would improve performance over nontreated heifers and have the same performance effects as monensinfed dairy heifers.

\section{MATERIALS AND METHODS}

\section{Animals, Diets, and Treatments}

This experiment was reviewed and approved by the University of Minnesota Institutional Animal Care and Use Committee (protocol no. 1505-32595A). The study used 84 Holstein dairy heifers from 3 commercial dairy farms in Minnesota. Calves arrived at the dairy facility within 1 wk of birth. Heifers began the study and were housed at the Southern Research and Outreach Center Calf and Heifer Research Facility from 91 to $161 \mathrm{~d}$ of age (June 2015 to September 2015). Eighty-four approximately 13-wk-old Holstein heifers were housed in a naturally ventilated curtain sidewall, straw-bedded barn in 12 pens with 7 heifers/pen $\left(3.98 \mathrm{~m}^{2} /\right.$ head $)$ for $70 \mathrm{~d}$ (3 pens per treatment). Bunk space was $0.522 \mathrm{~m} /$ heifer. Across treatments, pen age averaged $91.1 \pm 3.33$ $\mathrm{d}$ and $\mathrm{BW}$ averaged $109 \pm 7.55 \mathrm{~kg}$ per heifer (mean \pm $\mathrm{SD})$.

Heifers were randomly assigned to 1 of 4 treatments in a completely randomized design: (1) control $(\mathbf{C O N}$; carrier, $908 \mathrm{~g}$ of ground corn), (2) monensin (MON; 1 $\mathrm{mg} / \mathrm{kg}$ of BW + carrier), (3) cinnamaldehyde (CIN1; $1 \mathrm{mg} / \mathrm{kg}$ of BW + carrier), and (4) cinnamaldehyde (CIN2; $2 \mathrm{mg} / \mathrm{kg}$ of $\mathrm{BW}+$ carrier). These doses were based on the results of a sequential elimination taste preference experiment (Chapman et al., 2016). The dosage of the treatments was based on average pen BW and adjusted biweekly. The treatments were handmixed into a $20 \% \mathrm{CP}$ whole shell corn and protein pellet mix. Heifers had access to free choice hay from the same bale and water daily. A commercial whole shelled corn and pellet concentrate mixture (Hubbard Feeds Inc., Mankato, MN) containing 20.5\% CP (DM basis) was fed to heifers at $15.47 \mathrm{~kg} /$ pen $(2.21 \mathrm{~kg} /$ head $)$ daily. Cinnamaldehyde ( $\geq 95 \%$, Sigma-Aldrich Corp., St. Louis, MO) and monensin pellet (2 g/454 g; Hubbard Feeds Inc.) were hand-mixed in the ground corn carrier and then hand-mixed into the whole shell corn and protein pellet mix at $0900 \mathrm{~h}$ daily (except on weigh days when feeding occurred immediately after measurements and blood samples were taken). After the concentrate mixture and treatments were consumed (within $30 \mathrm{~min}$ of feeding), free choice hay was given. Nutrient analyses of the hay, concentrate mixture, and monensin pellet are shown in Table 1.

\section{Measurements and Blood Sampling}

Grower concentrate mix and hay intake per pen were recorded daily. Body weights and hip heights $(\mathbf{H H})$ were measured initially on $\mathrm{d} 1$ and then on d 14, 28, 42,56 , and 70 of the study. Calves were weighed in a manual squeeze chute (Pearson Livestock Equipment, Thedford, NE) with a digital scale (Rice Lake Weighing Systems, Rice Lake, WI). Hip heights were measured with a sliding scale height stick with a bubble level. Body condition scores (Wildman et al., 1982) were recorded on $\mathrm{d} 1$ and 70 of the study. Fecal samples were taken from the same 3 heifers/pen initially (d 1) and then on $\mathrm{d} 28,56$, and 70 of the study for coccidia counts by stimulating defecation or collected directly from the rectum. Methods for fecal floats for coccidia counting 
Table 1. Nutrient analysis of hay and whole shell corn and protein pellet mix (DM basis)

\begin{tabular}{lccc}
\hline Item & $\begin{array}{c}\text { Alfalfa/grass } \\
\text { hay }^{1}\end{array}$ & $\begin{array}{c}\text { Concentrate } \\
\text { mixture }^{2}\end{array}$ & $\begin{array}{c}\text { Monensin } \\
\text { sodium pellet }\end{array}$ \\
\hline DM, \% & 86.5 & 92.3 & 91.7 \\
CP, \% & 18.0 & 20.5 & 17.9 \\
Fat, \% & 1.54 & 4.49 & 3.69 \\
ADF, \% & 31.6 & 6.82 & 15.1 \\
NDF, \% & 43.4 & 9.25 & 32.5 \\
Starch, \% & - & 43.8 & 23.1 \\
Ash, \% & 10.6 & 6.23 & 8.64 \\
Ca, \% & 1.80 & 1.12 & 6.42 \\
P, \% & 0.31 & 0.67 & 0.69 \\
Mg, \% & 0.32 & 0.32 & 0.36 \\
K, \% & 2.90 & 1.02 & 0.91 \\
\hline
\end{tabular}

${ }^{1}$ Hay fed ad libitum to all heifers.

${ }^{2}$ Concentrate mixture was offered up to $2.21 \mathrm{~kg}$ (DM basis per head per day).

were determined by the modified Wisconsin sugar fecal worm egg flotation method (Bliss and Kvasnicka, 1997). Heifers were evaluated daily for visual signs of illness.

Blood samples were also taken (0800-1000 h) before feeding on d 1, 14, 28, 42, 56, and 70 of the study to determine plasma urea nitrogen (PUN), glucose, and IGF-1 concentrations. Blood samples were collected on weigh days via jugular venipuncture using 7 -mL tubes (BD Vacutainer, Becton Dickinson, Franklin Lakes, NJ) without anticoagulant and 20-gauge needles. Blood samples were centrifuged at $1,121 \times g$ for 20 min (5702, Eppendorf North America Inc., Westbury, $\mathrm{NY}$ ). Serum was stored at $-20^{\circ} \mathrm{C}$ until further analysis. Serum glucose concentrations were measured in duplicate using Wako Autokit for Glucose (Wako Diagnostics, Mountain View, CA). Concentrations were read on a DU 520 spectrophotometer according to manufacturer's instructions (Beckman Coulter Inc., Brea, CA). Analyses of PUN concentrations were measured in duplicate using the diacetyl-monoxime method and performed colorimetrically using an UV/visible spectrophotometer (Beckman Coulter Inc., Brea, CA) set at a wavelength of $540 \mathrm{~nm}$. Plasma concentrations of IGF-I were determined in duplicate by radioimmunoassay (Echternkamp et al., 1990; Funston et al., 1995) for all blood samples. Insulin-like growth factor binding proteins (IGFBP) were extracted from plasma using a 1:17 ratio of sample to acidified ethanol $(12.5 \% 2$ $N$ HCl: $87.5 \%$ absolute ethanol; Daughaday et al., 1980). Extracted samples were centrifuged $(12,000 \times$ $g$ at $4^{\circ} \mathrm{C}$ ) to separate IGFBP. A portion of the resulting supernatant was removed and neutralized with $0.855 M$ Tris base, incubated for an additional $4 \mathrm{~h}$ at $4^{\circ} \mathrm{C}$, and then centrifuged at $12,000 \times g$ at $4^{\circ} \mathrm{C}$ to remove any additional IGFBP. When samples of this extract, equivalent to the original plasma sample, were subjected to Western ligand blot analysis and subsequent phosphorimagery, no detected binding of $\left[{ }^{125} \mathrm{I}\right]$ IGF-I to IGFBP was observed. Inhibition curves of the neutralized extracted plasma ranging from 12.5 to 50 $\mathrm{mL}$ were parallel to the standard curve. Recombinant human IGF-I (GF-050; Austral Biological, San Ramon, $\mathrm{CA}$ ) was used as the standard and radioiodinated antigen. Antisera AFP 4892898 (National Hormone and Peptide Program, National Institutes of Diabetes, Digestive and Kidney Diseases, Bethesda, MD) was used at a dilution of 1:62,500. Sensitivity of the assay was $23.91 \mathrm{pg} /$ tube. Recovery of $\left.{ }^{125} \mathrm{I}\right] \mathrm{IGF}-\mathrm{I}$ added to porcine serum before extraction averaged $91 \pm 5 \%$. Intra-assay coefficient of variation was $8.9 \%$, and interassay coefficient of variation was $9.3 \%$.

\section{Feed Analysis}

Grower concentrate samples were collected once weekly and composited for analysis. Each bale of hay was core-sampled and composited for analysis. Samples were dried in a forced hot-air convection oven at $55^{\circ} \mathrm{C}$ for $48 \mathrm{~h}$ (Binder, Bohemia, NY). The composited samples were then ground through a 1-mm screen using a Wiley Mill (Thomas Scientific, Swedesboro, NJ). Samples were sent to Analab (Fulton, IL) for analysis of ADF (method 973.18); NDF (method 2002.04); CP (method 990.03); starch (enzymatic method using glucose Trinder); crude fat (method 920.39); ash (method 942.05); Ca, P, Mg, and K (method 985.01); and S (method 923.01) according to AOAC International methods (AOAC International, 1999). Nutrient analyses of the hay, concentrate mixture, and monensin sodium pellet are shown in Table 1 .

\section{Statistical Analysis}

All data were analyzed on a pen basis and then converted to mean values before statistical analyses. Weekly DMI, hay intake, ADG, BW change, ADG/ DMI, skeletal measurements, and blood metabolites were analyzed as a completely randomized design using repeated measures determined in the MIXED procedure of SAS (Version 9.4, SAS Institute Inc., Cary, NC) according to the following model:

$$
Y_{i j}=\mu+T_{i}+W_{j}+T W_{i j}+E_{i j},
$$

where $Y_{i j}=$ the dependent variable; $\mu=$ the overall mean; $T_{i}=$ the effect of the $i$ th treatment (CON, MOD, CIN1, or CIN2); $W_{j}=$ the effect of time (biweekly) $(j$ $=0 \ldots 10) ; T W_{i j}=$ the effect of interaction between the 
Table 2. Intake and performance of heifers during the 70-d trial

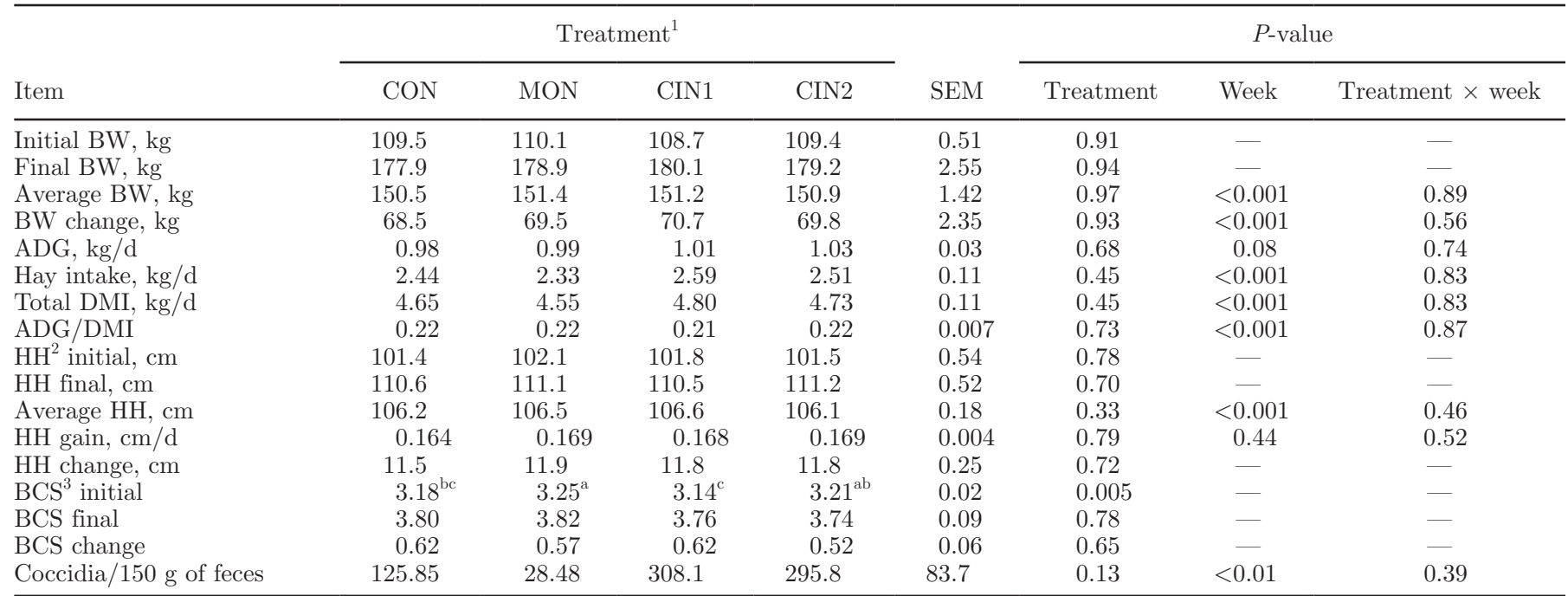

${ }^{\mathrm{a}-\mathrm{c}}$ Means with different superscripts differ $(P=0.005)$.

${ }^{1} \mathrm{CON}=$ carrier, $908 \mathrm{~g}$ of ground corn; MON $=1 \mathrm{mg} / \mathrm{kg}$ of BW of monensin sodium + carrier; CIN1 $=1 \mathrm{mg} / \mathrm{kg}$ of BW of cinnamaldehyde + carrier; CIN2 $=2 \mathrm{mg} / \mathrm{kg}$ of BW of cinnamaldehyde + carrier.

${ }^{2} \mathrm{HH}=$ hip height.

${ }^{3} \mathrm{BCS} 1$ to $5 ; 1=$ thin and $5=$ fat.

$i$ th treatment and the $j$ th week; $E_{i j}=$ the residual error $\sim N\left(0, \sigma^{2}\right)$; and $\sigma^{2}$ is the population standard deviation.

Initial BW, skeletal measurements, and blood metabolites of pens were used as covariates in the experimental design. Week was used as the repeated measure. Data were examined using 4 covariance structures: unstructured, compound symmetry, Toeplitz, and firstorder autoregressive. For first-order autoregressive, block was considered random. The covariance structure with the smaller Bayesian information criterion value was selected. Degrees of freedom were calculated using the Kenward-Roger approximation option of the MIXED procedure. Least squares means were determined for each treatment and the Tukey's option of SAS was selected to differentiate least squares means among treatments. Significance treatment effects were determined at a probability of $P \leq 0.05$, and trends were defined as $0.05<P \leq 0.10$.

\section{RESULTS}

Intake and growth data are presented in Table 2. Initial BW of heifers were not different among treatments. Because heifers were limit fed the concentrate mixture of $2.21 \mathrm{~kg} /$ heifer daily, no differences existed in concentrate intake across treatments. Hay intake, DMI, $\mathrm{ADG}$, and feed efficiency as expressed by ADG/DMI were also similar across treatments. On average, heifers consumed $2.48 \mathrm{~kg} / \mathrm{d}$ of hay throughout the $70-\mathrm{d}$ study and gained $0.2 \mathrm{~kg}$ of BW per kilogram of DMI. Average daily gains were $0.98,0.99,1.01$, and $1.03 \mathrm{~kg} / \mathrm{d}$, and average hay intakes per pen were 17.08, 16.34, 18.11, and $17.60 \mathrm{~kg} / \mathrm{d}$ for CON, MON, CIN1, and CIN2, respectively. Initial BCS was different between treatments $(P$ $<0.05$ ) because of high variation within heifers across pens, but no differences were observed in BCS change across treatments, with the treatments averaging 3.78 by the end of the study. No differences existed across treatments for initial $\mathrm{HH}, \mathrm{HH}$ change, $\mathrm{HH}$ gain, or final $\mathrm{HH}$.

Fecal samples by pens indicated the presence of viable coccidia, but the counts were low and not consistent across heifers within each pen (Table 2). The observed effect of week $(P<0.01)$ indicated that the longer the calves remained in the experiment, the lower the coccidia counts. Coccidia (eggs/150 g of feces) decreased from 373.36 (wk 4) to 12.16 (wk 10).

Plasma concentrations of IGF-1, PUN, and glucose are presented in Table 3 . All 3 metabolites were similar among treatments, with no treatment-by-week interactions.

\section{DISCUSSION}

Currently, no studies have been conducted to evaluate the effects on performance or blood metabolites of feeding essential oils to dairy heifers. The dose of cinnamaldehyde used in this study was based on a sequential elimination experiment to determine the taste preferences of 6 postweaned dairy heifers provided with 
Table 3. Blood metabolites of heifers during the 70-d trial

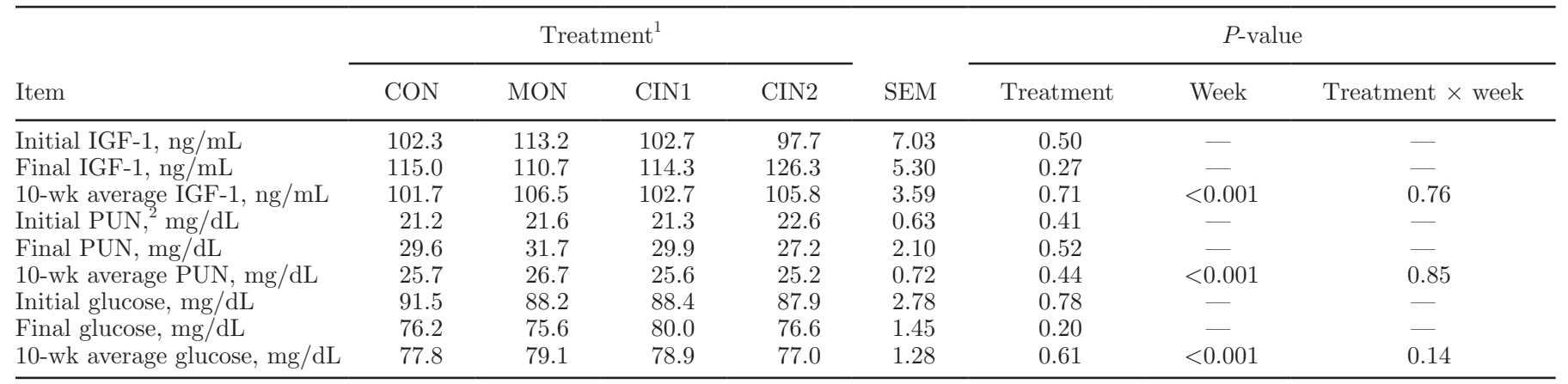

${ }^{1} \mathrm{CON}=$ carrier, $908 \mathrm{~g}$ of ground corn; MON $=1 \mathrm{mg} / \mathrm{kg}$ of BW of monensin sodium + carrier; CIN1 $=1 \mathrm{mg} / \mathrm{kg}$ of BW of cinnamaldehyde + carrier, and CIN2 $=2 \mathrm{mg} / \mathrm{kg}$ of BW of cinnamaldehyde + carrier.

${ }^{2} \mathrm{PUN}=$ plasma urea $\mathrm{N}$.

0 (control), 1, 2, 3, or $4 \mathrm{mg} / \mathrm{kg}$ BW of cinnamaldehyde daily (Chapman et al., 2016). Overall ranking of the 5 treatments were control, 2, 1, 3, and $4 \mathrm{mg} /$ $\mathrm{kg}$ BW of cinnamaldehyde. Results indicate that heifers preferred diets without cinnamaldehyde; however, when only cinnamaldehyde diets remained, DMI was not negatively affected regardless of the concentration of cinnamaldehyde provided (Chapman et al., 2016). Producers often observe a decrease in DMI when cattle receive feeds containing monensin compared with nonmedicated feeds (Erickson et al., 2004); however, no differences in DMI were seen in this current study. In a meta-analysis evaluating data from 22 published studies with dairy cows and beef steers fed monensin, Appuhamy et al. (2013) observed a negative correlation between DMI and monensin dose of -0.44 for cows and -0.41 for steers indicating that monensin reduces DMI. Average hay intake was $2.47 \mathrm{~kg} / \mathrm{d}$ and average DMI was $4.68 \mathrm{~kg} / \mathrm{d}$, and these results were similar to other data for heifers of that age fed monensin $(4.75$ $\mathrm{kg} / \mathrm{d}$, Raeth-Knight et al., 2009) or lasalocid $(5.0 \mathrm{~kg} / \mathrm{d}$, Cabral et al., 2013). The 1 and $2 \mathrm{mg} / \mathrm{kg}$ treatments of cinnamaldehyde were chosen for the current study; however, a greater dose of cinnamaldehyde could have shown different results. Also, heifers consumed all of their treatments once daily and within 30 min of feeding. Adding cinnamaldehyde to a TMR available over the day may possibly have yielded different results.

Essential oils, specifically cinnamaldehyde, have been studied in feedlot cattle (Yang et al., 2010; Vakili et al., 2013) and lactating dairy cows (Tassoul and Shaver, 2009; Tekippe et al., 2013; Wall et al., 2014), and differences in DMI response and performance have been observed. Feedlot cattle were fed supplemental cinnamaldehyde at 3 doses $(400,800$, or $1,600 \mathrm{mg} / \mathrm{d})$ to determine intake, growth performance, carcass characteristics, and blood metabolite differences compared with monensin (330 mg/d; Yang et al., 2010). The authors confirmed that the response to cinnamaldehyde is dose dependent because DMI responded quadratically to cinnamaldehyde supplementation, with $13 \%$ more feed consumed compared to control during the first $28 \mathrm{~d}$ of the study. Vakili et al. (2013) evaluated the effects of thyme and cinnamaldehyde $(5 \mathrm{~g} / \mathrm{d})$ on growth performance, ruminal fermentation, and blood metabolites in feedlot calves fed high-concentrate diets. These authors found that neither thyme nor cinnamaldehyde affected DMI, ADG, or feed efficiency, which disagrees with Yang et al. (2010). They stated the effects of essential oils on DMI might vary with the source of essential oil, the type of diet, diet interactions, or adaptations of the rumen microbial population to the different essential oils.

Studies have shown conflicting results concerning DMI, feed efficiency, and milk production when essential oils are fed to lactating dairy cows. Multiparous Holstein cows were fed a mixture of essential oils (Crina; DSM Nutritional Products Inc.) targeted for $1.2 \mathrm{~g} / \mathrm{d}$ (Tassoul and Shaver, 2009). Crina is a patented blend of natural and natural-identical essential oil compounds including thymol, eugenol, vanillin, and limonene in an organic carrier. Results showed no difference between treatments for actual or fat-corrected milk yields; however, feed efficiency ( $\mathrm{kg}$ of milk per $\mathrm{kg}$ of DMI) tended to be greater for cows receiving the essential oil supplement on average (Tassoul and Shaver, 2009). Tekippe et al. (2013) conducted 3 experiments to study the effects of an essential oil product, which contained a blend of $17 \%$ cinnamaldehyde and $28 \%$ eugenol (0, control, or $525 \mathrm{mg} / \mathrm{d}$, Xtract 6965; Pancosma SA, Geneva, Switzerland) and observed no effect of DMI between treatments and minimal effects on rumen fermentation. Wall et al. (2014) studied the effects of Xtract 6965 in varying doses of 200,350,400, or 600 $\mathrm{mg} / \mathrm{d}$ for 6 to $8 \mathrm{wk}$ on the milk production of lactating Holstein multiparous and primiparous dairy cows. 
The researchers observed that this blend of essential oils was associated with an increase in DMI in both parity groups, with an increase in milk production only occurring in multiparous cows with a $350 \mathrm{mg} / \mathrm{d}$ dose; however, Tekippe et al. (2013) fed the same product and observed no effects of DMI. Wall et al. (2014) concluded that a blend of cinnamaldehyde and eugenol can increase DMI and milk production in lactating dairy cows; however, it appears that the optimal dose might depend on the parity of the animal. How essential oils modulate feed intake is unclear, but the effect might be partly attributed to the observed apparent improvement in rumen function and increased fiber digestibility (Tekippe et al., 2013).

No differences were seen in ADG among treatments. Average daily gains were $0.98,0.99,1.01$, and $1.03 \mathrm{~kg} / \mathrm{d}$ for CON, MON, CIN1, and CIN2, respectively. Our data are in agreement with Golombeski et al. (2010) who observed similar ADG in Holstein dairy heifers fed a combination of essential oils. In their review of available data, Sejrsen and Purup (1997) concluded that a feeding level resulting in growth rates above 600 to 700 $\mathrm{g} / \mathrm{d}$ can have a permanent negative effect on mammary growth and future milk production. The data also suggested that the negative effect of feeding level is limited to the prepubertal phase of mammary development (3-9 mo of age) when mammary growth is sensitive to a high feeding level. However, currently, studies are showing the benefits of increasing prepubertal ADG on mammary growth milk yield, which conflicts with the conclusions of Sejrsen and Purup (1997). Zanton and Heinrichs (2005) conducted a meta-analysis of 8 studies over the past 15 years evaluating changes in $\mathrm{ADG}$ and $\mathrm{BW}$ at calving on first lactation production of milk, FCM, milk fat, and milk protein. They found a quadratic response with increasing prepubertal ADG on milk yield. They also found that first lactation production increased as prepubertal gains increased up to $799 \mathrm{~g} / \mathrm{d}$; however, that was the point of maximal milk production, and further increases in prepubertal ADG were associated with lower milk production. In that model, which accounted for differences in calving weight, milk production was maximal at prepubertal ADG of $836 \mathrm{~g} / \mathrm{d}$. Milk protein yield was also maximized when prepubertal growth occurred at $836 \mathrm{~g} / \mathrm{d}$, and yield of milk fat remained relatively constant independent of alterations in prepubertal ADG. These authors suggest that any gain above $800 \mathrm{~g} / \mathrm{d}$ would result in a decrease in milk protein and milk yield in the first lactation; however, the meta-analysis does not take into account whether the heifers' weight gain was from lean muscle growth or body condition, and it does not indicate the type of diet fed to these heifers. Heifers in the current study averaged $1 \mathrm{~kg} / \mathrm{d}$ of $\mathrm{BW}$ gain.
Monensin improves feed efficiency, increases rate of gain, and controls coccidiosis (Haney and Heohn, 1967). Improved feed efficiency is associated with increased concentration of propionic acid and decreased concentrations of acetic and butyric acid in the rumen when monensin is fed (Raun et al., 1974; Van Nevel and Demeyer, 1998; Calsamiglia et al., 2007; Benchaar et al., 2008). However, feeding monensin sodium in the current study to postweaned dairy heifers did not affect any of the performance parameters measured in comparison with the control or cinnamaldehyde treatments. Average feed efficiency defined by ADG/DMI for all heifers was 0.22 .

Monensin has a mode of action that specifically targets the Eimeria parasite (Chapman et al., 2010). Essential oils have been shown to be effective against Eimeria species in poultry, and it may also be effective against Eimeria in bovines as well (Hume et al., 2006). However, fecal samples by pens indicated the presence of viable coccidia, but the counts were low and not consistent across heifers within each pen.

Essential oils can interact with microbial cell membranes and inhibit the growth of some gram-positive and gram-negative bacteria, which inhibits deamination and methanogenesis, resulting in lower ammonia $\mathrm{N}$, methane, and acetate concentrations and greater propionate and butyrate concentrations (Calsamiglia et al., 2007). An increase in baseline urea concentrations is considered to indicate $\mathrm{N}$ excess and inefficiency of protein feeding. However, no blood metabolites (IGF-1, PUN, or glucose) were affected by treatment, and they were similar to other data for heifers of that age (Chelikani et al., 2009; Anderson, et al., 2015). Plasma urea nitrogen concentrations were elevated compared with those in many studies. This result could be attributed to the consumption of the concentrate portion of the diet in a short period $(30 \mathrm{~min})$, the $\mathrm{CP}$ of the alfalfa hay $(18 \%)$, or the concentrate $(20 \%)$ used in the study (Table 1).

Prepubertal mammary growth in heifers is dependent on the interactions of many hormones and growth factors, some of which are stimulatory while others are inhibitory (Purup et al., 2000). Growth hormone stimulates mammary growth through increasing the hepatic synthesis of IGF-1, which is a potent mitogen for mammary cells and may be a major factor in the control of mammary development during the prepartum period. However, IGF-1 data showed a lot of variation and no differences among treatments.

Feeding cinnamaldehyde to dairy heifers did not affect any performance measures in this study. Because antibiotic growth promoters are losing favor because of the appearance of residues in livestock products and possible development of antibiotic-resistant bacteria, 
more research needs to focus on natural alternatives such as essential oils. Investigating their possible influences on feed efficiency and animal productivity as well as their prevention of coccidiosis would be critical in the evolution of the dairy industry.

\section{CONCLUSIONS}

Feeding cinnamaldehyde or monensin sodium to weaned dairy heifers did not affect any of the performance parameters measured compared with nontreated heifers. Increasing the dose of cinnamaldehyde or changing the way it was administered may have resulted in a different outcome. Currently, no other studies have fed cinnamaldehyde-only oils to heifers, and more research is needed to determine if cinnamaldehyde is effective in improving heifer performance. The conditions of the experiment were such that cattle experienced little stress and performed well regardless of treatment. Our results might have been different if the heifers were housed in a more stressful environment or if the heifers were fed diets in the form of a TMR. The cost of heifer rearing is expensive, and if supplementing with essential oils, such as cinnamaldehyde, could improve heifer health status and feed utilization, thus increasing rate of gain and future productivity, dairy operations could decrease their overall cost of feeding and managing replacement heifers. Future research regarding supplemental essential oils to dairy heifers should focus on different doses of essential oils and a new way to administer the treatment, which may affect feed efficiency and disease incidence in dairy heifers.

\section{ACKNOWLEDGMENTS}

The authors thank the George Walker Fund and the New Hampshire Agricultural Experiment Station. This study is Scientific Contribution Number 2686. This work was supported by the USDA National Institute of Food and Agriculture (Washington, DC; NC-2042; accession number 1001283). We thank the farm staff at the Calf and Heifer Facility at the University of Minnesota Southern Research and Outreach Center for allowing the use of their calves and helping with measurements and sampling, and Hubbard Feeds Inc. (Mankato, MN) for the concentrate mixture and monensin pellet.

\section{REFERENCES}

Anderson, J. L., K. F. Kalscheur, J. A. Clapper, G. A. Perry, D. H. Keisler, A. D. Garcia, and D. J. Schingoethe. 2015. Feeding fat from distillers dried grains with solubles to dairy heifers: II. Effects on metabolic profile. J. Dairy Sci. 98:5709-5719.

AOAC International. 1999. Official Methods of Analysis. 16th ed. AOAC International, Gaithersburg, MD.
Appuhamy, J. A. D. R. N., A. B. Strathe, S. Javasundara, C. WagnerRiddle, J. Dijkstra, J. France, and E. Kebreab. 2013. Anti-methanogenic effects of monensin in dairy and beef cattle: A metaanalysis. J. Dairy Sci. 96:5161-5173.

Benchaar, C., S. Calsamiglia, A. V. Chaves, G. R. Fraser, D. Colombatto, T. A. McAllister, and K. A. Beauchemin. 2008. A review of plant-derived essential oils in ruminant nutrition and production. Anim. Feed Sci. Technol. 145:209-228.

Bento, M. H. L., A. C. Ouwehand, K. Tiihonen, S. Lahtinen, P. Nurminen, M. T. Saarinen, H. Schulze, T. Mygind, and J. Fischer. 2013. Essential oils and their use in animal feeds for monogastric animals - Effects on feed quality, gut microbiota, growth, performance, and food safety: A review. Vet. Med. (Praha) 58:449-458.

Bliss, D. H., and W. G. Kvasnicka. 1997. The fecal examination: A missing link in food animal practice. Compend. Contin. Educ. Pract. Vet. 19(4 Suppl.):S104-S109.

Burt, S. 2004. Essential oils: Their antibacterial properties and potential applications in foods - A review. Int. J. Food Microbiol. 94:223-253.

Cabral, R. G., P. S. Erickson, N. E. Guindon, E. J. Kent, C. E. Chapman, K. M. Aragona, M. D. Cabral, E. C. Massa, N. T. Antaya, C. C. Muir, B. O'Donnell, and M. E. Branine. 2013. Effects of lasalocid and intermittent feeding of chlortetracycline on the growth of prepubertal dairy heifers. J. Dairy Sci. 96:4578-4585.

Cady, R. A., and T. R. Smith. 1996. Economics of heifer raising programs. Pages 7-24 in Proc. Calves, Heifers, and Dairy Profitability Natl. Conf. Harrisburg, PA. Northeast Reg. Ag. Eng. Serv. NRAES-74, Ithaca, NY.

Calsamiglia, S., M. Busquet, P. W. Cardozo, L. Castillejos, and A. Ferret. 2007. Essential oils as modifiers of rumen microbial fermentation: A review. J. Dairy Sci. 90:2580-2595.

Chapman, C. E., R. G. Cabral, K. M. Aragona, and P. S. Erickson 2016. Short communication: Cinnamaldehyde taste preferences of weaned dairy heifers. J. Dairy Sci. 99:3607-3611.

Chapman, H. D., T. K. Jeffers, and R. B. Williams. 2010. Forty years of monensin for the control of coccidiosis in poultry. Poult. Sci. 89:1788-1801.

Chelikani, P. K., D. J. Ambrose, D. H. Keisler, and J. J. Kennelly. 2009. Effects of dietary energy and protein density on plasma concentrations of leptin and metabolic hormones in dairy heifers. J. Dairy Sci. 92:1430-1441.

Cowan, M. M. 1999. Plant products as antimicrobial agents. Clin. Microbiol. Rev. 12:564-582.

Daughaday, W. H., I. K. Mariz, and S. L. Blethen. 1980. Inhibition of access of bound somatomedin to membrane receptor and immunobinding sites: A comparison of radioreceptor and radioimmunoassay of somatomedin in native and acid-ethanol-extracted serum. J. Clin. Endocrinol. Metab. 51:781-788.

Echternkamp, S. E., L. J. Spicer, K. E. Gregory, S. F. Canning, and J. M. Hammond. 1990. Concentrations of insulin-like growth factor-I in blood and ovarian follicular fluid of cattle selected for twins. Biol. Reprod. 43:8-14.

Erickson, P. S., M. L. Davis, C. S. Murdock, K. E. Pastir, M. R. Murphy, C. G. Schwab, and J. I. Marden. 2004. Ionophore taste preferences of dairy heifers. J. Anim. Sci. 82:3314-3320.

Funston, R. N., G. E. Moss, and A. J. Roberts. 1995. Insulin-like growth factor-I (IGF-I) and IGF-binding proteins in bovine sera and pituitaries at different stages of the estrous cycle. Endocrinology 136:62-68.

FDA (US Food and Drug Administration). 2004. 21CFR184: Direct food substances affirmed as generally recognized as safe. Accessed Feb. 17, 2016. https://www.accessdata.fda.gov/scripts/cdrh/ cfdocs/cfcfr/CFRSearch.cfm?CFRPart $=184 \&$ showFR $=1$

Golombeski, G., B. Ziegler, D. Schimek, D. Ziegler, H. Chester-Jones, M. Raeth-Knight, and J. Linn. 2010. Performance of post-weaned Holstein heifer calves fed grain mixes supplemented with essential oils at differing levels. J. Anim. Sci. 88(E-Suppl. 3):102. (Abstr.)

Haney, M. E. Jr., and M. M. Heohn. 1967. Monensin, a new biologically active compound. I. Discovery and isolation. Antimicrob. Agents Chemother. 7:349-352. 
Hume, M. E., S. Clemente-Hernández, and E. O. Oviedo-Rondón. 2006. Effects of feed additives and mixed Eimeria species infection on intestinal microbial ecology of broilers. Poult. Sci. 85:21062111.

Purup, S., M. Vestergaard, and K. Sejrsen. 2000. Involvement of growth factors in the regulation of pubertal mammary growth in cattle. Adv. Exp. Med. Biol. 480:27-43.

Raeth-Knight, M., H. Chester-Jones, S. Hayes, J. Linn, R. Larson, D. Ziegler, B. Ziegler, and N. Broadwater. 2009. Impact of conventional or intensive milk replacer programs on Holstein heifer performance through six months of age and during first lactation. J. Dairy Sci. 92:799-809.

Raun, A. P. C. O. Cooley, R. P. Rathmacher, L. F. Richardson, and E. L. Potter. 1974. Effect of different levels of monensin on feed efficiency, ruminal and carcass characteristics of cattle. Proc. Western Sec. Am. Soc. Anim. Sci. 25:346.

Sejrsen, K., and S. Purup. 1997. Influence of prepubertal feeding level on milk yield potential of dairy heifers: A review. J. Anim. Sci. $75: 828-835$

Tassoul, M. D., and R. D. Shaver. 2009. Effect of a mixture of supplemental dietary plant essential oils on performance of periparturient and early lactation dairy cows. J. Dairy Sci. 92:1734-1740.

Tekippe, J. A., R. Tacoma, A. N. Hristov, C. Lee, J. Oh, K. S. Heyler, T. W. Cassidy, G. A. Varga, and D. Bravo. 2013. Effect of essential oils on ruminal fermentation and lactation performance of dairy cows. J. Dairy Sci. 96:7892-7903.

USDA. 2007. Dairy 2007. Part I: Reference of Dairy Cattle and Management Practices in the United States, 2007. https://www. aphis.usda.gov/animal_health/nahms/dairy/downloads/dairy07/ Dairy07_dr_PartI.pdf.
Vakili, A. R., B. Khorrami, M. Danesh Mesgaran, and E. Parand. 2013. The effects of thyme and cinnamon essential oils on performance, rumen fermentation and blood metabolites in Holstein calves consuming high concentrate diet. Asian-australas. J. Anim. Sci. 26:935-944.

Van Nevel, C. J., and D. I. Demeyer. 1998. Manipulation of rumen fermentation. Pages 387-443 in The Rumen Microbial Ecosystem. P. N. Hobson, ed. Elsevier Applied Science, New York, NY.

Venkitanarayanan, K., A. Kollanoor-Johny, M. J. Darre, A. M. Donoghue, and D. J. Donoghue. 2013. Use of plant-derived antimicrobials for improving the safety of poultry products. Poult. Sci. 92:493-501.

Wall, E. H., P. H. Doane, S. S. Donkin, and D. Bravo. 2014. The effects of supplementation with a blend of cinnamaldehyde and eugenol on feed intake and milk production of dairy cows. J. Dairy Sci. 97:5709-5717.

Wildman, E. E., G. M. Jones, P. E. Wagner, R. L. Boman, H. F. Troutt Jr., and T. N. Lesch. 1982. A dairy cow body condition scoring system and its relationship to selected production characteristics. J. Dairy Sci. 65:495-501.

Yang, W. Z., B. N. Ametaj, C. Benchaar, M. L. He, and K. A Beauchemin. 2010. Cinnamaldehyde in feedlot cattle diets: Intake, growth performance, carcass characteristics, and blood metabolites. J. Anim. Sci. 88:1082-1092.

Zanton, G. I., and A. J. Heinrichs. 2005. Meta-analysis to assess effect of prepubertal average daily gain of Holstein heifers on firstlactation production. J. Dairy Sci. 88:3860-3867. 